\title{
ASSESSMENT AND RISK MANAGEMENT OF SOCIO-ECONOMIC PROJECTS
}

\author{
Olesia lastremska', Olha Korolenko ${ }^{2}$
}

\begin{abstract}
The quality of implementation of social programs and projects is a measure of the effectiveness of social policy. Ideally, a social project can be implemented if absolutely everyone is interested: both the participants and those to whom the project affects in one way or another. All stakeholders are members of the value chain and add value to the program to one degree or another. The general purpose of the research work is to substantiate the mechanisms for reconciling the interests of stakeholders and study effective models of social entrepreneurship. Practice proves that the most rational among the known methods of risk management is the stakeholder approach. The main risks in the perception of the quality of social project implementation are "gaps": a) in knowledge - project implementers misunderstanding of the customer expectations; $b$ ) in standards - the inability to set quality standards that meet customer expectations; c) in the effect of implementation - the inability to ensure the quality of project implementation in relation to established standards; e) in communications - the inconsistency of the transmitted information about the quality of the project to the actual level. All these risks are closely linked. Research shows that the greatest risks in the implementation of social projects occur among the "gaps" in standards.

Distinctive features of the management process of social programs and projects, which have to be taken into account during the management standards development, are presented in the work of V.M. Burkov. The basis of the formation of the interests harmonization mechanism is the "Stakeholder Interaction Standard AA1000" (Standard AA1000SES), which sets out the basic methods, tools and standards of stakeholders management. The technology of developing of the social project road map is presented in the work of O.V. Ponomarenko. The works of O.I. Datsko are devoted to the study of the role of stakeholders in the view of the projects development with the aim to increase the territories competitiveness. The process of urban development strategy is researched by A.I. Yermolova. Summarizing the above, it should be noted that one of the defining areas of socialization of economic relations in modern Ukraine is the development of social entrepreneurship. Today's economic, political and social realities necessitate the development of social entrepreneurship from the level of charity to the level of social enterprises, which will not only become a source of material needs for people unable to compete in the labor market, but also help to solve various pressing social problems. The formation of social enterprises should be ensured by a set of legal, economic and ideological guarantees from the state and society. The evolution of social entrepreneurship should be accompanied by the solution of both global (for example, the formation of public consciousness) and applied (for example, for the sustainable social entrepreneurship development it is required to use effective business models) tasks. The method of CBA involves determining the discount rate for social projects, which can be calculated by the model for the assessment of the social border of intertemporal benefits. The following statistical indicators can be used for calculation: the risk to life level, the growth rate of consumption per capita, the elasticity of the marginal social utility of consumption. The calculation uses the arithmetic mean values of these indicators for as long as possible.
\end{abstract}

Key words: social entrepreneurship, social project, social project risk, discount rate, CBA-analysis, business models, social development.

JEL Classification: A13, O10, G14, L84, O31

\footnotetext{
Corresponding author:

${ }^{1}$ Simon Kuznets Kharkiv National University of Economics, Ukraine.

E-mail: Iastremska.o@gmail.com

ORCID: https://orcid.org/0000-0003-1865-0282

${ }^{2}$ Kryvyi Rih National University, Ukraine.

E-mail: korolenko.ob@knu.edu.ua

ORCID: https://orcid.org/0000-0002-0771-4298
} 


\section{Introduction}

Today, the modern development of society is impossible without future planning with the strategic possibility of stable socio-economic progress, which is the socially oriented growth that provides the social innovation, including unusual ways of solving and mitigation of existing social problems. A market economy is based on the "three whales": legal system, market infrastructure, and entrepreneurship. According to international experience, an important component of the national economy competitiveness is entrepreneurship.

In the conditions of market transformation of the Ukrainian economy, the entrepreneurship development is the basis of economic and social development, social problems solving, poverty overcoming and the high standard of living ensuring. Entrepreneurship has been developing since Ukraine had got independence.

The quality of implementation of social programs and projects is the measure of the social policy effectiveness. Ideally, the social project can be implemented if absolutely everyone is interested in its realization: the participants and those whom the project affects in one or another way. All stakeholders are members of the value chain and they add value to the program to some extent. The social value optimization for consumers is complicated by the fact that stakeholders of one value chain are members of many other value chains that together constitute the social capital of the program or territory. In order to increase this capital, it is necessary to use standards and methods of program (project) risk management. The practice proves that among the known methods of risk management the most rational is the stakeholder approach.

The general purpose of the research is to substantiate the mechanisms of stakeholders interests harmonization and coordination of management entities actions, to develop the risk assessment methods and to consider them as the methodological basis for the social project management standardization at the regional level.

\section{Methodology of research}

The issues related to the state socio-economic development and the social development of the enterprise are given considerable attention by M. Volkova, N. Holubiak, N. Horishna, H. Davydovska, V. Dykan, O. Dovhan, V. Kompaniets, M. Naumova, E. Plakhova. At the same time, despite the significant number of scientific works, which consider theoretical, methodological, practical aspects of socio-economic development of the state, the social entrepreneurship remains unresolved, and some positions are still debatable. Despite the significant contribution made by domestic and foreign scholars to the research problem, there is a need for further in-depth study and consideration at both theoretical and practical levels.

The main risks in the perception of the quality of social project implementation are "gaps": a) in knowledge project implementers misunderstanding of the customer expectations; b) in standards - the inability to set quality standards that meet customer expectations; c) in the effect of implementation - the inability to ensure the quality of project implementation in relation to established standards; e) in communications - the inconsistency of the transmitted information about the quality of the project to the actual level. All these risks are closely linked. Research shows that the greatest risks in the implementation of social projects occur among the "gaps" in standards.

Many works by both national and foreign specialists are devoted to the project management methodology implementation in the field of state regulation of social development, namely S. D. Bushuiev, V. N. Burkov, V. Voropaiev, V. M. Vorotin, Clifford, F. Gray, N. M. Dragomiretska, I. I. Mazura, V. D. Shapiro etc. Problems of development of the social services market are investigated by M. F. Holovatyi, I. D. Zvereva, H. M. Laktionov, T. V. Semihina, E. I. Kholostov etc. V. I. Hrebennikov, B. A. Rosenfeld, N. M. Rymashevska etc. pay attention to the social standards development. Scientific research by V. B. Ahranovych, N. V. Kulikova, O. V. Ponomarenko are devoted to the issue of standardization of the social programs management. The matter of the social engineering methodologies is studied by A. S. Avtonomov, H. A. Antoniuk, A. S. Karpovtseva, V. A. Lukov etc.

Distinctive features of the management process of social programs and projects, which have to be taken into account during the management standards development, are presented in the work by V. M. Burkov. The basis of the formation of the interests' harmonization mechanism is the "Stakeholder Interaction Standard AA1000" (Standard AA1000SES), which sets out the basic methods, tools and standards of stakeholders management. The technology of developing of the social project road map is presented in the work by O. V. Ponomarenko. The works by O. I. Datsko are devoted to the study of the role of stakeholders in the view of the projects development with the aim to increase the territories competitiveness. The process of urban development strategy is researched by A. I. Yermolova.

Despite the significant scientific interest in solving the problem of the stakeholders management, it is still missing the high quality systematic study of existing methodological approaches to the formation of stakeholder management technology with an emphasis on defining the problem area of coordination of interests and conflict prevention in social projects and programs. Consequently, it has determined the subject area of our research. 
We also emphasize that today several approaches to social project management have been developed, the structural components of the social project have been identified, the goals of setting problems in social engineering have been carefully considered, optimal schemes of social project implementation and financing have been revealed, the process of project team formation and project participants management have been identified.

Additionally, in the works devoted to the analysis of the investment projects risks, project risks are classified, numerous methods of their qualitative and quantitative assessment are developed, the scheme of the project risks analysis and management methods are described. However, in the existing works the issue of quantitative risk assessment of social projects is not considered. Accordingly, it has led to the main scientific tasks within the research.

\section{The formation of approaches to the social entrepreneurship definition as the basis of research}

Social entrepreneurship - the entrepreneurial activity combined with the solution of social problems, it is activities the results of which are evaluated not only (and not so much) by the amount of profit, but by the "social return".

The theoretical platform of the social entrepreneurship scientific research is the concept of "mixed" or "combined value" of J. Emerson (J. Emerson), according to which the enterprise is an element of socio-economic reality, which combines economic and social components. At the same time, these components are not considered in isolation, but as complementary. According to J. Emerson, the results of economic and social activities cannot be opposed. "The question is not what to choose - the creation of economic wealth or social improvement, but to create values and use resources to increase the benefits of continuous production of both types (economic and social)" (Social Business In UA, 2020).

The concept of combined value is based on the following components: all enterprises create combined value; there is a continuous interaction of social and economic goals of the enterprise; assessing of the investments effectiveness by financial instruments only leads to the efficiency underestimation in general. Although J. Emerson's concept indicates the social nature of any economic activity, but it does not allow to explain the features of social enterprises.

Several concepts of social enterprise are defined at the doctrinal level: broad, combined, innovative and problem oriented.

The broad approach (E. Shaw, J. Viravardena, G. Mort, A. Fowler, The Center for the Advancement of Social Entrepreneurship) is based on the hypothesis that social entrepreneurship is an activity that ultimately implies the achievement of the social goal. According to this approach, social entrepreneurship means the activities of state social organizations; traditional business organizations, which always have a social component; non-governmental non-profit organizations. The broad approach does not allow to single out and define the features of social entrepreneurship, as it can include any activity that has the social effect. In the projection on domestic realities, it is practically impossible to find an enterprise (even if its activities are far from socially oriented, such as production associated with harmful emissions into the atmosphere), which would not declare its positive significance for the economic interests of society in modern Ukraine (for example nuclear energy).

The combined (commercial-social) approach (A. Macmillan, J. Robinson, J. Rogalin) assumes that social entrepreneurship is an activity focused on achieving not only social but also commercial results. According to this approach, social entrepreneurship is a field of activity that requires the business component. This approach is implemented in Ukraine through the system of legal incentives, such as preferential taxation of employers for creating additional jobs for people who find it difficult to compete in the labor market.

The innovative approach (J. Meyer, E. Noboa, E. Austin, J. Wei-Skillern, H. Stevenson, F. Perrini, S. Vurro) emphasizes on the innovative component of entrepreneurship and the innovative approaches application to solve the social problems. The innovative approach, on the one hand, significantly limits the scope of social entrepreneurship compared to the combined approach because not all business organizations use innovation in the social component of their activities. Similarly, the activities of non-profit organizations and state social institutions that do not implement innovations do not fall under social entrepreneurship. On the other hand, this approach expands social entrepreneurship by supplementing its activities with non-profit organizations and public social institutions that develop and implement innovations in their activities. From our point of view, such approach is realistic in Ukraine with the support of international organizations and charitable foundations.

Problem oriented approach (K. Lidbiter, Schwaba Foundation) refers to social entrepreneurship such activity, the social results of which are focused on the particular social group or problem (people with disabilities, socially vulnerable groups, migrants, homeless others). This approach can be considered as a kind of broad approach but with limitations in the field of social entrepreneurship and potential consumers of its products or services.

There is still no common vision of social entrepreneurship in the international practice, in particular regarding the criteria for the attitude 
of enterprises to social, business mechanisms for solving social problems, community building and mutual assistance. In the United States, for example, it is enough for a product or service to solve a certain social problem, and then the enterprise that produces this product or provides a service can already be called social. In Europe, the approach is slightly different: social enterprises have to give part of the profit to the social projects or provide employment to people with special needs. However, there is one criterion with which everyone agrees - it is the social effect, a certain public good. Whatever the differences in the social entrepreneurship definition, the purpose of this activity is to help society. This is a real mechanism of using social opportunities and solving social problems. The more people hear about it, the greater effect this mechanism will create.

On the base of the pluralism of social entrepreneurship approaches and practices, it is advisable to clarify its essence as a socio-economic phenomenon. Entrepreneurship in its modern sense is the creative initiative process of searching and application of creative or not realized opportunities (innovations) of profit increasing of its economic activity in order to obtain additional entrepreneurial income by a business entity. At the same time, entrepreneurial income is a part of profit generated from the realization of the ability of the business entity to innovation. According to this definition, entrepreneurship is not identified with business. Business is any initiative economic activity of its subjects for making profit. So, social entrepreneurship means systematic, including innovative, economic activity, which involves solving social problems.

The main result of the social enterprise should be the creation of a certain social value. Unlike the traditional business, where the main result is profit, social value is a rather complex category, because it refers to both financial and non-financial results (European Commission (2020)).

Considering the social entrepreneurship, social value is a certain benefit for society that is created by business through entrepreneurial activity. It should be the main purpose of the social enterprise. A tool of social value creation is often a product or service

\section{Experience of social entrepreneurship development in the European countries}

The European social enterprises have regional features and the clear social goal, to the realization of which they direct the significant part of their profits. For example, most German social enterprises solve the problems of vulnerable groups: migrants and refugees, unemployed youth and people with disabilities. The Kiron International Platform enables refugees to get education and qualifications remotely - anywhere and anytime. Social Impact has also been operating in Germany for over 20 years, supporting and advising social enterprises, positioning itself as a "social innovation agency". In 2011, Social Impact launched the incubation program Social Impact labs, which became a platform for social entrepreneurs and freelancers.

Social entrepreneurs are credited by federal banks, venture funds are invested in them, crowdfunding and group investments are gaining popularity. As a result, there are about 100,000 social enterprises in Germany, employing more than 2.5 million workers, that is three times more than the car industry, which employs 750,000 workers (Chien-Chung H. and Blair D., 2018).

Social enterprises in developed countries are, firstly, representatives of small and medium-sized businesses, which play a key role in job creation and economic development - it should be the priority for Ukraine as well. According to the European Commission, there are currently two million social enterprises in Europe (10\% of all European business) with more than 11 million employees ( $6 \%$ of workers in the region). The main organizational and legal forms of social enterprises in European countries are cooperatives (in particular, in Portugal - "social solidarity cooperatives", in France "social cooperatives of collective ownership", in Italy "social cooperatives", in Spain - "cooperatives of social initiatives" etc.) or companies (for example, in the UK - "community-based companies", in Belgium "social purpose companies") (European Commission (2020).

Three countries (Lithuania, Slovakia and Finland) have adopted laws that define social enterprises as engaged exclusively in the labor integration of vulnerable groups.

The European Commission identifies four main areas in which social enterprises operate:

- work integration - training and integration of people with disabilities and the unemployed;

- provision of personal social services - health, welfare and medical care, vocational training, education, medical services, child care services, services for the elderly or assistance to low-income people;

- local development of areas located in disadvantaged areas - social enterprises in remote rural areas, schemes of development / rehabilitation of neighborhoods in urban areas, development assistance and cooperation with third countries;

- other, including processing of agricultural products, environmental protection, sports, art, culture and historical preservation, science, research and innovation, protection of the rights of consumers and sports fans (Richardson, 2016).

Regarding the sources of the social enterprises financing, the experience of developed countries shows that fees and sales (own revenues) were the most important source of financing in $54.28 \%$ of enterprises, followed by grants $-27.11 \%$, donations - 
$5.96 \%$ and investments - $4.61 \%$. At the same time, the distribution of funding sources differs significantly between countries. Thus, financing from own revenues ranges from $74.5 \%$ in Spain to $28.5 \%$ in Romania. Grants range from $36.2 \%$ in Sweden to $18.9 \%$ in China, and donations range from $12.1 \%$ in Romania to $1.7 \%$ in Hungary. Investments range from $21 \%$ in China to 0.6\% in Spain (European Commission, 2020).

The study conducted by the European Commission in 2018 notes that significant amounts of social services are also funded by the public sector. For example, approximately $45 \%$ of social enterprises in Italy are supported by state funds and they are their main clients (Chien-Chung H. and Blair D., 2018).

\section{Risk management of social projects}

The research on modern technologies of social engineering has made it possible to emphasize the importance of forecasting the consequences of a social project for stakeholders. On this basis, the analysis was conducted. It was determined that social forecasting in the social project was to determine the future results of the social project and assess their positive and negative consequences for the social system as a whole, the target group and / or individual social groups. This is the most time-consuming and long-term activity, which involves extrapolation and interpolation of certain trends in social development, analytical models development (matrix, simulation, game, etc.), often - the experts survey. The social forecasting is needed due to the high cost of possible negative consequences of social innovations, which can provoke an unpredictable reaction of society and minimize the positive social effect obtained because of the project.

Let us say that the marketing of social projects is a process of identifying the needs of society or individual social groups developing and implementing the strategy for their most effective satisfaction within the project resources. The main purpose of marketing activities in social engineering is to find out the optimal scheme for achieving project goals, i.e. the expected social effect. In the process of the social project developing and implementing, marketing activities consist of: implementation of social diagnostics, i.e. collection and analysis of information in order to identify problem areas of the social sphere; assessment of the capabilities of state and municipal structures or non-profit organizations and the cultural potential of society to meet public needs or solve social problems; determination of the main characteristics of the project product; social forecasting, i.e. determining the future results of the social project and assessing their positive and negative consequences for the social system as a whole; development and implementation of the project product promotion strategy including positioning of public value related to the product.
Social projects are being developed to meet the needs of citizens or to solve certain social problems by changing the social situation. The reason for the social projects development is mostly such problems that, firstly, have contradictory multi-vector development trends, and, secondly, need an adequate solution. The originality of social projects is expressed in the fact that the main expert in their evaluation is not the state or the customer of the project, but society. Therefore, the acceptability of solving social problems options for the target groups of the project and the population of the region for which it is developed, should be one of the indicators of the quality of the social project.

So, the criteria for the social project acceptability in relation to the population of its territory include public awareness of the importance of social innovation, which is provided by the project; public assessment of the degree (or probability) of achieving the project objectives; the attitude of the population to the ways of the goals achievement; forecast activity of the population in the project implementation.

Suppose the introduction of an integrated index of acceptability of the social project can be used in order to compare alternatives to the same project, and to select the most popular project for society. In the process of the stakeholder analysis, the following tasks can be solved: development and approval of the strategy; making adjustments to the project; improving the project development and implementation process; ensuring reporting by project co-executors; increasing the level of knowledge about the advantages and disadvantages of the project, etc.

The advisability of such actions during the stakeholder analysis: identification of the project stakeholders; determining the importance of each of the stakeholders for the project; determining the interest of each party and the degree of impact on the project; determining the emotional commitment of project stakeholders; determining the strategy and tactics of interaction with each of the stakeholders; inclusion of measures for interaction with stakeholders in the project schedule.

Quantitative risk analysis of social projects is defined by modern regulations as a necessary component; the assessment of project effectiveness should also be carried out taking into account all risk factors. The main purpose of this analysis is to establish and provide to investors, potential partners or project participants the data that is necessary for the decision-making on the expediency of participation in the project.

When reviewing the methods of quantitative assessment of project risks, their advantages, disadvantages, and analysis of their acceptability allow us to conclude that in theory and practice there are no universal methods that can be used for any social project. Potential investors and project developers should be able to choose methods taking into account the specific conditions of the project, time and money, the scale of 
the social project, its strategic characteristics. Therefore, the risk assessment of large-scale social projects with the aim to solve highly significant social problems associated with long-term results causes serious difficulties. There is the need to find a compromise between possible losses due to inaccurate assessment and forecasting results and costs for their improvement.

The determination of the discount rate for social projects can be calculated by the model for the assessment of the social border of intertemporal benefits. According to this method, we have calculated the discount rate for Ukrainian social projects. For 2021 it is $4.37 \%$. The forecast discount rate for the period 2018-2021 by the method of scenario analysis was following: in 2018 it ranged from $4.06 \%$ to $5.15 \%$ with the most probable value of $4.58 \%$; in 2020 , the SPTR took a value from $3.73 \%$ to $5.55 \%$ (forecast), and in 2021 the social discount rate is projected to fluctuate from $3.0 \%$ to $4.85 \%$ (Sencha, 2013).

The obtained values of the social discount rate can be used as a marginal assessment by the developers of social projects proposed for implementation in the region.

1. The index of acceptability of social projects application is necessary in modern Ukraine. As many social problems require the development and implementation of many relevant projects, the index allows to compare projects on such important characteristics as acceptability for the population of their territory and reject or postpone such projects, which definitely will not have significant support from the population. It will reduce the risk of wrong management decisions in the public sector and increase public confidence to government.

However, it should be noted that the proposed methodology provides only assessment of the acceptability of the social project by the population, without taking into account the acceptability of the project for the target group and the project team. Therefore, further research requires the methodology development that would allow to obtain a comprehensive assessment of the acceptability of the social project in quantitative terms.

2. In the process of the stakeholder analysis, the following tasks can be solved: development and approval of the strategy; making adjustments to the project; improving the project development and implementation process; ensuring reporting by project co-executors; increasing the level of knowledge about the advantages and disadvantages of the project, etc. Further research requires the issue of methodological approaches to stakeholder management in the technology of developing social projects, especially at the level of local communities.

3. The risk assessment of large-scale social projects with the aim to solve highly significant social problems associated with long-term results causes serious difficulties. There is the need to find a compromise between possible losses due to inaccurate assessment and forecasting results and costs for their improvement. Taking into account the importance of the problem, further research is needed to improve methods and techniques of risk accounting in the assessment of the social project's effectiveness (Martunyuk, 2019).

4. The CBA (cost-benefit analysis) application, i.e. estimating the ratio of costs for social projects and benefits from it during the examination of social projects is necessary in modern Ukraine, as the application of this analysis allows to compare the monetary equivalent of social effects from their implementation and reject clearly ineffective projects at the stage of their preliminary evaluation, which will reduce the risk of wrong management decisions in the public sector and optimize budget expenditures (Kriuchkov, 1998).

\section{Conclusions}

Summarizing the above, it should be noted that one of the defining areas of socialization of economic relations in modern Ukraine is the development of social entrepreneurship. Current economic, political and social realities necessitate the development of social entrepreneurship from the level of charity to the level of social enterprises, which will not only become a source of material needs for people unable to compete in the labor market, but also help to solve various pressing social problems. The formation of social enterprises should be ensured by a set of legal, economic and ideological guarantees from the state and society. The evolution of social entrepreneurship should be accompanied by the solution of both global (for example, the formation of public consciousness) and applied (for example, for the sustainable social entrepreneurship development it is required to use effective business models) tasks.

It should be noted that social entrepreneurship is a sustainable and positive form of social change that ensures the development of society, the ability of the community to ensure their own economic independence, stability and prosperity. Despite political and economic instability, low level of financial support from the state, Ukraine has great domestic potential and strong intellectual resources for the social entrepreneurship development. We believe that social entrepreneurship in modern realities is aimed to accelerate positive social changes, ensuring the satisfaction of basic human needs in an optimal way. It should be the key factor in the sustainable development not only of the individual area, but also of the state as a whole.

The method of CBA involves determining the discount rate for social projects, which can be calculated by the model for the assessment of the social border of intertemporal benefits. The following statistical indicators can be used for calculation: the risk to life level, the growth rate of consumption per capita, and the elasticity of the marginal social utility of consumption. 
The calculation uses the arithmetic mean values of these indicators for as long as possible.

However, it is important to note that the proposed method of calculating the social discount rate is suitable only for short-term and medium-term planning, as the time series of available statistics are very short. In addition, the approach of the social border of intertemporal benefits does not take into account the specific risks of projects, so the further research requires the calculation of the social discount rate for long-term planning taking into account industry specifics.

\section{References:}

AA 1000 SES (2017). Standart vzaimodeistviia storonami [Stakeholder Engagement Standard]. Available at: www.accountability.org.uk (accessed 17 November 2020).

Burkov, V. N., Burkova, I. V., \& Gorgidze, I. A. (2005). Zadachi upravleniia v sotcialnykh i ekonoichskikh sistemakh [Tasks of management in social and economic systems]. Moscow: SINTEZ.

Datsko, O. I. (2011). Zastosuvannia tsinnisnoho pidkhodu dlia zabezpechennia konkurentospromozhnosti rehionu v umovakh hlobalizatsii [Implementation of value-based approach to provide competitiveness of the region in the context of globalization]. Visn. Donets.nats. un-tu, vol. 1, pp. 67-90.

Yermolova, A. I. (2012). Model seredovyshcha zatsikavlenykh storing rozrobky stratehii rozvytku mista [Model of the environment of stakeholders in creating urban development strategy]. Available at: http:/ /archive.nbuv.gov.ua/ portal/Soc_Gum/VSUNU/2012_14_1/Ermolova.pdf (accessed 17 November 2020).

Kriuchkov, Iu.A. (1998). Teoriia i metody sotcialnogo proektirovaniia [Theory and methodology of social project planning]. Moscow: MGP "Informreklamizdat".

Martunyuk, O., Vitvitskaya, O., Lagodiienko, V., \& Krupitsa, I. (2019). Formation of an innovative concept of management on the basis of reconstruction of genetic algorithm of management technology. Periodicals of Engineering and Natural Sciences. Periodicals of Engineering and Natural Sciences, vol. 7, no. 2, pp. 487-499. Available at: http://pen.ius.edu.ba/index.php/pen/article/view/560

Sencha, I. A. (2013). Metodyka kilkisnoi otsinky pryiniatnosti sotsialnykh proektiv dlia suspilstva [Methodology for quantitative assessment of acceptability of social projects for society]. Publichne upravlinnia: teoriia ta praktyka, vol. 1(13), pp. 97-102.

Sencha, I. A. (2013). The method of quantitative evaluation is social projects for society. Public administration: theory and practice: coll. science. etc. Association of Doctors of Science in Publ. Admin. Kharkiv: Dok-NaukDerzhUpr Publishing House.

Toshchenko, Zh. T., Antov, N. A., \& Lapin, N. I. (1982). Social design. Moscow: Mysl.

Social business in UA (2020). "About social entrepreneurship". Available at: www.socialbusiness.in.ua (accessed 08 January 2020).

Chien-Chung, H. and Blair, D. (2018). “The Development of Social Enterprise: Evidence from Europe, North America, and Asia”, Research Report March. Available at: https: socialwork.rutgers.edu/sites/default/files/report (accessed 08 January 2020).

Dees, G. (1998). “The Meaning of Social Entrepreneurship”, Article_Dees_Meaningof Social Entrepreneurship. Available at: https:centers.fuqua.duke.edu/case (accessed 08 January $\overline{2} 020$ ).

Richardson, M. (2016). "Social Enterprise: Lessons learned in the UK”, Dopovid na II Vseukrainskomu forumi sotsialnykh pidpryiemtsiv [Report at the II All-Ukrainian Forum of Social Entrepreneurs]. Kyiv, Ukraine, November 16.

European Commission (2020). "Sectors of the Social economy in the EU: Social enterprises". Available at: https://ec.europa.eu/growth/sectors/social-economy/enterprises_en (accessed 08 January 2020). 